\title{
Correction to: Introduction: The Lacanian Woman and Lars von Trier's Cinema
}

\section{Correction to}

Chapter 1 in: A. Elbeshlawy, Woman in Lars von Trier's Cinema, 1996-2014, https://doi.org/10.1007/978-3-319-40639-8_1

Owing to an oversight, a comment was published inadvertently in the text which has now been removed.

The updated original online version of this chapter can be found at https://doi.org/10.1007/978-3-319-40639-8_1 